\title{
Hydrogen sulfide removal from geothermal fluids by Fe(III)-based additives
}

\author{
S. Regenspurg ${ }^{1 *} \mathbb{E}$, J. lannotta ${ }^{2}$, E. Feldbusch ${ }^{1}$, F. J. Zimmermann ${ }^{1}$ and F. Eichinger ${ }^{2}$
}

\author{
*Correspondence: \\ regens@gfz-potsdam.de \\ ${ }^{1}$ Helmholtz Centre Potsdam \\ GFZ German Research \\ Centre for Geosciences, \\ 14473 Potsdam, Germany \\ Full list of author information \\ is available at the end of the \\ article
}

\begin{abstract}
A new method to remove hydrogen sulfide from geothermal fluids during well operation was tested in situ at a geothermal site in Vienna (Austria). For this purpose, ferric iron was added either as granulated iron hydroxide or as $\mathrm{FeCl}_{3}$ solution into a reaction vessel containing the thermal water directly removed from the wells. From the container, the water would be pumped through a particle filter. Physicochemical parameters as well as sulfide were measured constantly over time before and after the filter. It was found that the sulfide was fully removed from the water by both iron additives. While the addition of $\mathrm{FeCl}_{3}$ led first to the formation of black iron(II) sulfide (FeS), which subsequently oxidized in presence of oxygen to Fe(III) hydroxide, no visible change of the granulated iron hydroxide was observed. The reaction time was longer when using the $\mathrm{Fe}(\mathrm{III})$ hydroxide additive as compared to the $\mathrm{FeCl}_{3}$ (completed in less than $20 \mathrm{~min}$ ) but could be enhanced by increasing the amount of added particles. In all experiments the $\mathrm{pH}$ was constantly rising during the reaction from about 6.3 to 7.5 , which was explained by loss of protons due to purging out of the gaseous $\mathrm{H}_{2} \mathrm{~S}$. The redox value, which was measured over time, remained rather constant after addition of granulated iron hydroxide (about $-350 \mathrm{mV}$ ), but strongly increased from $-350 \mathrm{mV}$ to $-50 \mathrm{mV}$ after adding the $\mathrm{FeCl}_{3}$ suggesting a strong electron-consuming reaction. This can be explained by a two-step reaction: first, the Fe(III) was reduced to Fe(II) by oxidation of either sulfide or thiosulfate to sulfate. Afterward, the Fe(II) oxidized again by dissolved oxygen forming orange Fe(III) hydroxides. The application of the investigated method during operation of geothermal wells could prevent $\mathrm{H}_{2} \mathrm{~S}$-induced corrosion and would eliminate the toxic effects of this gas.
\end{abstract}

Keywords: Geothermal fluid, Hydrogen sulfide, Removal of $\mathrm{H}_{2} \mathrm{~S}$, Iron additive, Iron sulfur redox system

\section{Introduction}

Hydrogen sulfide $\left(\mathrm{H}_{2} \mathrm{~S}\right)$ containing geothermal fluids is known from all over the world. High $\mathrm{H}_{2} \mathrm{~S}$ brines are most frequently connected to volcanic activities as found in areas of Iceland (Kristmannsdóttir 2005) or Indonesia (Nasution et al. 2000). And also carbonate aquifers such as those of the South German Molasse Basin are known to have high $\mathrm{H}_{2} \mathrm{~S}$ (Mayrhofer et al. 2014). Solutions to remove this toxic and corrosive gas from geothermal fluids are highly needed for a sustainable operation of geothermal plants. Hydrogen sulfide not only occurs typically together with other volcanic gases such as $\mathrm{CO}_{2}(\mathrm{Hansell}$ 
and Oppenheimer 2004) or together with natural methane as sour gas $\left(\mathrm{CH}_{4}+\mathrm{H}_{2} \mathrm{~S}\right)$, but it can also be produced in soil and ground water by sulfate-reducing microorganisms that decompose organic matter in the absence of oxygen (anaerobic digestion). In general, $\mathrm{H}_{2} \mathrm{~S}$ forms when elemental sulfur $\left(\mathrm{S}_{0}\right)$ comes in contact with organic material, especially at high temperatures (Berner 1985). Sulfur $\left(\mathrm{S}_{0}\right)$ and sulfate $\left(\mathrm{SO}_{4}{ }^{2-}\right)$-reducing bacteria derive energy from hydrogen or organic molecules by reducing sulfur or sulfate to hydrogen sulfide in the absence of oxygen $\left(\mathrm{O}_{2}\right)$. At low oxygen conditions sulfate-reducing bacteria use the sulfate present in the water to oxidize the organic matter, thereby producing hydrogen sulfide as waste. Thus, hydrogen sulfide occurs naturally in all types of waters that are depleted in oxygen.

$\mathrm{H}_{2} \mathrm{~S}$ only slightly dissolves in water at ambient conditions and only small proportions dissociate $\left(\mathrm{H}_{2} \mathrm{~S}+\mathrm{H}_{2} \mathrm{O} \rightarrow \mathrm{HS}^{-}+\mathrm{H}^{+}\right)$forming a weak acid $\left(\mathrm{pk}_{\mathrm{a}}=6.9\right)$. According to recent investigations by Raman spectroscopy, only $\mathrm{HS}^{-}$(and no $\mathrm{S}^{2-}$ ) anions are present in aqueous solutions (May et al. 2018). At pressures above 18 bar $\mathrm{H}_{2} \mathrm{~S}$ remains dissolved in water. The hydrogen sulfide can further react with aqueous metal ions to produce hardly soluble, dark-colored metal sulfides such as ferrous sulfide $\left(\mathrm{FeS}, \mathrm{FeS}_{2}\right)$. Due to the affinity of sulfide for iron, hydrogen sulfide is poisonous to the human body, because it binds to iron in the mitochondrial cytochrome enzymes, thus preventing cellular respiration and damaging especially the nervous system. While it is harmless at very low concentrations ( $<5 \mathrm{ppm})$, when the human body is able of detoxification processes by oxidizing sulfide to sulfate, already at $20 \mathrm{ppm}$ damages of the cornea have been reported (Reiffenstein et al. 1992). The lethal threshold is about 300 to $350 \mathrm{ppm}$, when the oxidative enzymes become overwhelmed (Ramasamy et al. 2006). By the human nose, however, its strong and unpleasant smell is already detectable in very small concentrations. Besides its toxic effect, $\mathrm{H}_{2} \mathrm{~S}$ can also be responsible for deterioration of materials causing severe corrosion damages (sulfide stress corrosion cracking) an effect that is also strongly enhanced by microorganisms (biogenic corrosion; Jia et al. 2018).

Many processes have been designed to remove hydrogen sulfide from drinking water such as chlorination (e.g., addition of hypochlorite that oxidizes the sulfide to solid $\mathrm{S}_{0}$ ), aeration (oxidation to sulfate at low concentrations), or nitrate addition (Baldacci et al. 2005). The effect of iron addition on sulfide removal was tested by Gultierrez et al. (2010) and Firer et al. (2008) for application in wastewater treatment. However, for the removal of $\mathrm{H}_{2} \mathrm{~S}$ from geothermal water operators typically keep the pressures high to prevent degassing. For application at low pressures additives could be an alternative option and should be tested experimentally. The main problems when performing experiments at geothermal-similar conditions are the increased temperature and pressure of these systems, which impede laboratory experiments especially when dealing with the toxic $\mathrm{H}_{2} \mathrm{~S}$ gas. This study offered the unique chance to test the suggested method of adding ferric iron ( $\mathrm{Fe}(\mathrm{III}))$ compounds in situ directly at a geothermal site into $\mathrm{H}_{2} \mathrm{~S}$ bearing brine. The underlying hypothesis of this process is that $\mathrm{Fe}(\mathrm{III})$ will be reduced to $\mathrm{Fe}(\mathrm{II})$ and the sulfide precipitates as iron sulfide $\left(\mathrm{FeS}\right.$ or $\mathrm{FeS}_{2}$ ) or oxidizes further to less-toxic sulfate anions $\left(\mathrm{SO}_{4}{ }^{2-}\right)$.

The following reactions are assumed to take place in $\mathrm{H}_{2} \mathrm{~S}$-containing systems: In $\mathrm{Fe}(\mathrm{III})$ solutions, the sulfide can act as electron acceptor and reduce the $\mathrm{Fe}(\mathrm{III})$ to $\mathrm{Fe}(\mathrm{II})$, while being oxidized to sulfate $\left(\mathrm{SO}_{4}^{2}\right.$; Eq. 1a, 1b, 1c): 


$$
\begin{aligned}
& \mathrm{Fe}^{3+}+\mathrm{e}^{-} \rightarrow \mathrm{Fe}^{2+}(\log K=13.02), \\
& \mathrm{HS}^{-}+4 \mathrm{H}_{2} \mathrm{O} \rightarrow \mathrm{SO}_{4}^{2-}+8 \mathrm{e}^{-}+9 \mathrm{H}^{+}(\log K=-33.69) .
\end{aligned}
$$

Log $\mathrm{K}$ given in brackets are from the databases included in the HYDRA/MEDUSA software (Puigdomenech 2004).

The two half reactions $1 \mathrm{a}$ and $1 \mathrm{~b}$ together result in

$$
8 \mathrm{Fe}^{3+}+\mathrm{HS}^{-}+4 \mathrm{H}_{2} \mathrm{O} \rightarrow 8 \mathrm{Fe}^{2+}+\mathrm{SO}_{4}^{2-}+9 \mathrm{H}^{+} .
$$

At reducing conditions, the formed $\mathrm{Fe}(\mathrm{II})$ can subsequently precipitate with sulfide to solid iron sulfide such as FeS (pyrotite; Eq. 2) or $\mathrm{FeS}_{2}$ (pyrite, marcasite; Eq. 3):

$$
\begin{aligned}
& \mathrm{HS}^{-}+\mathrm{Fe}^{2+} \rightarrow \mathrm{FeS}+\mathrm{H}^{+}(\log K=4.68), \\
& 2 \mathrm{HS}^{-}+\mathrm{Fe}^{2+} \rightarrow \mathrm{FeS}_{2}+2 \mathrm{H}^{+}+2 \mathrm{e}-(\log K=18.479) .
\end{aligned}
$$

In the presence of oxygen, both sulfide and $\mathrm{Fe}(\mathrm{II})$ can be oxidized to sulfate and $\mathrm{Fe}(\mathrm{III})$, respectively (Eq. 4 and 5 ).

$$
\begin{aligned}
& \mathrm{H}_{2} \mathrm{~S}+2 \mathrm{O}_{2} \rightarrow \mathrm{SO}_{4}^{2-}+2 \mathrm{H}^{+} \\
& 2 \mathrm{Fe}^{2+}+1 / 2 \mathrm{O}_{2}+5 \mathrm{H}_{2} \mathrm{O} \rightarrow 2 \mathrm{Fe}(\mathrm{OH})_{3}+4 \mathrm{H}^{+}
\end{aligned}
$$

With $\mathrm{Fe}(\mathrm{OH})_{3}$ representing simplified all kinds of iron(III) hydroxides such as goethite $(\mathrm{FeOOH})$ or ferrihydrite $\left(\mathrm{Fe}_{2} \mathrm{O}_{3}{ }^{*} 0.5 \mathrm{H}_{2} \mathrm{O}\right)$, the ferric iron hydroxides can be reduced at acidic conditions to ferrous (Fe(II); Eq. 6).

$$
\mathrm{Fe}(\mathrm{OH})_{3}+3 \mathrm{H}^{+}+\mathrm{e}^{-} \rightarrow \mathrm{Fe}^{2+}+3 \mathrm{H}_{2} \mathrm{O}(\log \mathrm{K}=-17.911)
$$

Based on Eqs. 1a-6, it was hypothesized that when Fe(III) is added to the thermal waters either as solid iron hydroxide or as a solution of $\mathrm{FeCl}_{3}$, it can be reduced by the sulfide while simultaneously acid will be consumed. The formed sulfate (Eq. 4) could be bound directly to the solid iron(III) hydroxide by specific adsorption, which is especially efficient in acid environment and releases surface hydroxide groups (Cornell and Schwertmann 2003; Eq. 7):

$$
\mathrm{SO}_{4}^{2-}+\equiv \mathrm{Fe}(\mathrm{OH})_{2} \rightarrow \equiv \mathrm{Fe}-\mathrm{SO}_{4}+2 \mathrm{OH}^{-}
$$

with " $\equiv$ " representing the iron oxide surface group.

Based on these assumptions, the removal of sulfide by Fe(III) addition seems likely. It should be noted, however, that by air oxygen only small amounts $(<2 \mathrm{mg} / \mathrm{L})$ of $\mathrm{H}_{2} \mathrm{~S}$ can be oxidized to sulfate and the kinetics of $\mathrm{H}_{2} \mathrm{~S}$ oxidation are relatively slow (Kovalenko et al. 2001). Moreover, the reactions (Eq. 1a-7) can be affected by other ions in solution especially oxygen, carbonate, the $\mathrm{pH}$, temperature, and the presence of microorganisms.

The present study investigates the removal of $\mathrm{H}_{2} \mathrm{~S}$ from the geothermal brine by $\mathrm{Fe}(\mathrm{III})$-based additives. In detail, it was aimed (i) to test the above-described method 
with two different Fe(III) species directly at a geothermal site, and (ii) to determine the kinetics of these reactions.

\section{Materials and methods}

\section{Site description}

The thermal bath Oberlaa is located in a Southern suburb of the city of Vienna. Its thermal water is used for heating the recreation area, which hosts up to two thousand people per day. Vienna is geologically situated in the Vienna Basin, a large sedimentary basin structure in central Europe stretching in SW-NE direction between the Alps, the Carpathians and the Pannonian Plain. Sedimentary layers of Miocene age that reach a maximum thickness of $5500 \mathrm{~m}$ are deposited in the basin (Goldbrunner 2010). In the area of the Vienna basin several geothermal sites have been developed, most of them serving as spas but at the site Bad Blumau additionally electricity, $\mathrm{CO}_{2}$, and heat are produced (Legman 2003). At Oberlaa, two geothermal wells (TH1 and TH2) have been drilled into a fault system down to $364 \mathrm{~m}$ producing water of $53{ }^{\circ} \mathrm{C}$ at a production rate of about $10 \mathrm{~m}^{3} / \mathrm{h}$ (each well; Zötl 1997). The water is of moderate salinity (3-4 g/L) and dominated by $\mathrm{Mg}, \mathrm{Ca}, \mathrm{SO}_{4}$, and $\mathrm{Cl}$ ions. Variable sulfide concentrations between 13 and $46 \mathrm{mg} / \mathrm{L}$ have been observed (unpublished reports). Currently, the operators add sulfuric acid and sodium hydroxide to the thermal water to clean it from $\mathrm{H}_{2} \mathrm{~S}$ and use it for bathing. For this procedure, the thermal water is first degassed by air stripping and addition of sulfuric acid, which removes the $\mathrm{H}_{2} \mathrm{~S}$ together with $\mathrm{CO}_{2}$ gas from the water. The $\mathrm{H}_{2} \mathrm{~S}$ enriched air flows over an absorber containing sodium hydroxide thus binding the gaseous $\mathrm{H}_{2} \mathrm{~S}$ to the aqueous phase again. The fluid mixture is then disposed to the sewage water and the desulfurized water is filtered over a gravel filter to remove precipitated gypsum and to eventually use the conditioned thermal water for bathing. The gravel filter has to be flushed back regularly and the backwash is collected as sewage water in a retention pool. The backwash and water from the conditioning steps lead to large-scale gypsum and carbonate precipitations. Since the use of chemicals such as sulfuric acid and sodium hydroxide is expensive and hazardous, it is of interest of operators to investigate alternative methods to reduce the hydrogen sulfide content of the thermal water.

\section{Experimental set-up}

Experiments were performed between the 18th and 20th of June 2019. Always a water volume ratio of 1:1 was produced from both wells (TH1 and TH2) and would flow from the wellheads into a $1-\mathrm{m}^{3}$ plastic container (IBC), where the additives were injected. Two different $\mathrm{Fe}(\mathrm{III})$ components were tested:

- Granular ferric hydroxide (GFH): This fine-grained, dark brown, weakly crystalline and porous iron hydroxide is a synthetically produced mixture of akaganeite ( $\beta$-FeOOH; $50-70 \%$ ), ferrihydrite, and other iron oxides with $43-48 \%$ of water that is commercially available (produced by US Filter, USA; Badruzzamann et al. 2004). GFH is often used as a selective adsorbent for the removal of toxic metals in drinking- and wastewater treatment. Typically, GFH with a grain size of $0.2-2 \mathrm{~mm}$ is used for filter systems. In this study, however, the fraction $<0.2 \mathrm{~mm}$ was used to achieve a better suspension and improved mixing of the particles in the reaction container. 
One $\mathrm{ml} \mathrm{GFH}$ corresponds to a dry mass of $0.51 \mathrm{~g}$. According to the product data sheet, the surface area of GFH as determined by the BET method is $300 \mathrm{~m}^{2} / \mathrm{g}$.

- $\mathrm{FeCl}_{3}$ stock solution (40\%): The dark red, highly acidic solution of p.a. grade was directly added to the reaction container.

The reaction container is equipped with a stirrer to enable quick and homogenous mixing (Fig. 1). In addition, an air compressor was connected to allow a strong mixing of the water with air oxygen. A flow-through cell containing a set of electrodes $(\mathrm{pH}$, redox, electric conductivity, and dissolved oxygen) was connected at the outlet of the reaction container. The additives were injected into the reaction container through an open hatch in the container lid (Fig. 1). From the container, the brine would pass first through a self-cleaning filter ("HydroGeoFilt"). This filter was recently designed and developed for use at geothermal sites (patent is to come) and is adapted to high temperature and pressure applications (e.g., thermal water). Five filter candles with different mesh sizes (here, 5, 10, 25, 50 and $100 \mu \mathrm{m}$ ) can be inserted (Fig. 1c). During backwashing an ultrasonic device installed in a stainless-steel case removes the filter cake from the filter candles. After the filter, the fluid flows through a monitoring device ("FluMo") that measures and records every minute $\mathrm{pH}$, redox (Eh), electric conductivity, density, and temperature (Fig. 1d; Milsch et al. 2013; Feldbusch et al. 2013). From the FluMo outflow (e), the water was either discarded into the sewage system or connected to the IBC container to ensure circulation of the fluid. Sample collection was possible at location d or directly from the IBC container (Fig. 1).

Before the actual experiment started, three quick pre-tests were conducted at the site to better define the system:

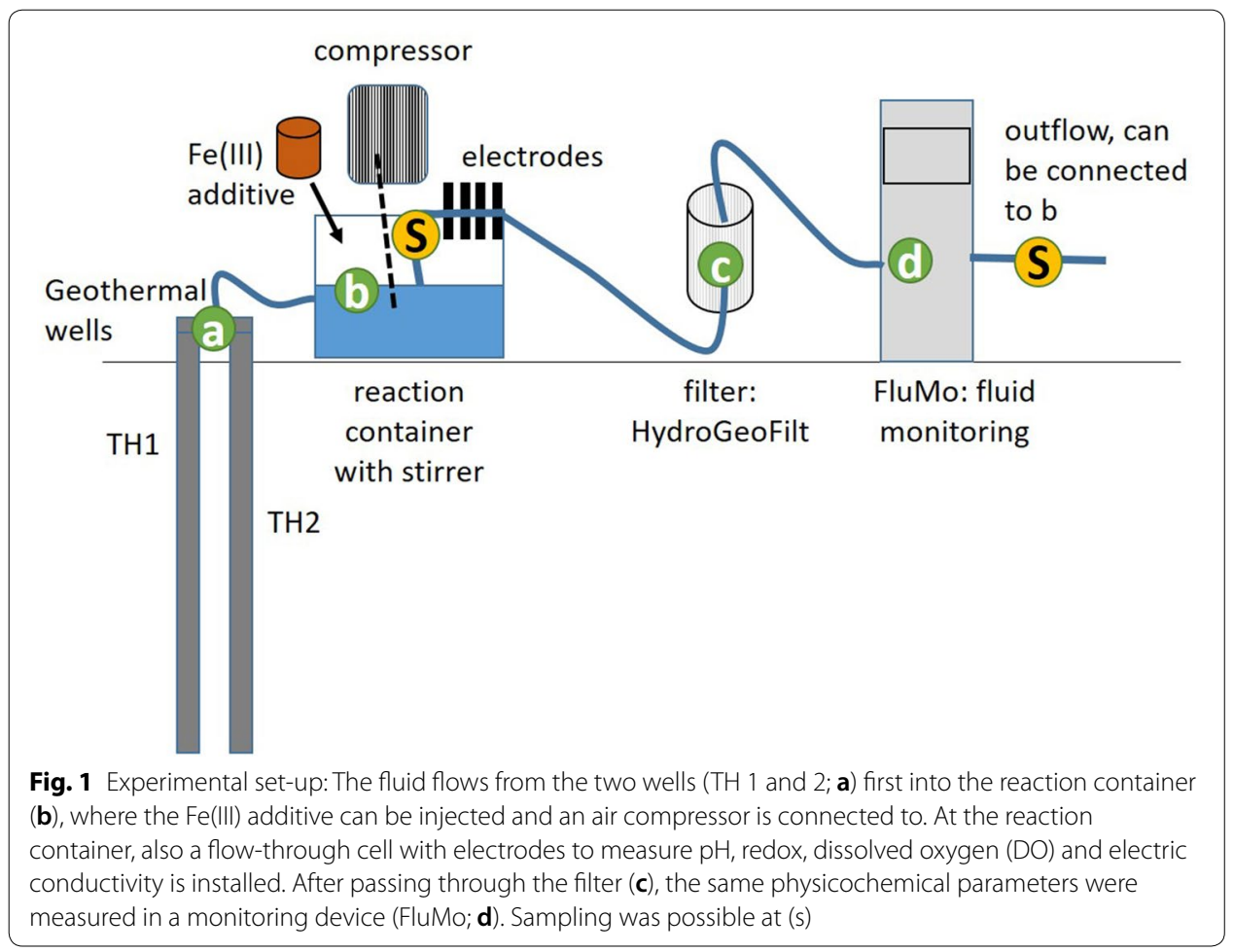




\section{Pre-experiment I}

To test the variability and ranges of chemo-physical parameters of the geothermal brine over time each $2 \mathrm{~L}$ water was collected directly from the wells (location a; Fig. 1) and the chemo-physical parameters were immediately measured by the same probes as those used in the IBC reaction container. This was repeated five times over 20 min and mean values and standard deviation were determined to obtain a baseline of the thermal water for $\mathrm{pH}$, redox, electric conductivity, and DO.

\section{Pre-experiment II}

Addition of GFH to the thermal water to estimate the speed of the reaction: $0.5 \mathrm{~mL}$ GFH was added to $400 \mathrm{~mL}$ fresh thermal water taken directly from the well at location a (corresponds to $0.64 \mathrm{~g}$ dry mass GFH/L water). Seven sub-samples were collected over 30 min and sulfide was measured photometrically therein (see Sect. "Large-scale flowthrough experiments").

\section{Pre-experiment III}

Experiment to determine the minimum amount of $\mathrm{FeCl}_{3}$ to be added to the thermal water to bind all sulfide: Since the $\mathrm{FeCl}_{3}$ stock solution $(40 \%$ or $4 \mathrm{M}$ ) reacts highly acidic $(\mathrm{pH}<0)$, a strong dilution with thermal water was needed to guarantee, on the one hand, a neutral $\mathrm{pH}$ value but to obtain, on the other hand, a sufficient amount of Fe for removing all solution sulfide. Various ratios of $\mathrm{FeCl}_{3}$ solution and thermal water were prepared $(1: 100,1: 1000,1: 10,000)$ and $\mathrm{pH}$ value and sulfide were measured immediately after mixing the two together.

\section{Large-scale flow-through experiments}

The following experimental settings based on the experimental set-up shown in Fig. 1 are summarized in chronological order in Table 1. In all experiments, $\mathrm{pH}$, redox (Eh), dissolved oxygen (DO), electric conductivity (EC), and temperature were measured directly in the reaction container outflow. Filtering and subsequent fluid monitoring were only done in experiments B, C, D, and E. Sample collection occurred either in the container or after the fluid monitoring device. During experiment $\mathrm{A}$, the thermal water just circulated in the reaction container and GFH was added in access. In experiment B, additionally the filter and the fluid monitoring device (FluMo) behind were connected. In experiment $\mathrm{C}$, again it was not only measured in the reaction container but this time also the effect of the compressor bubbling air into the reaction container was tested and the amount of GFH was reduced and added in two steps (each $0.1125 \mathrm{~g} / \mathrm{L}$ ).

Solely in experiment $\mathrm{E}$ the $\mathrm{FeCl}_{3}$ solution was added to the container (instead of $\mathrm{GFH}$ ).

\section{Analytical methods}

\section{Field analysis}

Sulfide was measured photometrically (Multilab P5) after acidifying the samples. Since the sulfide species $\mathrm{H}_{2} \mathrm{~S}, \mathrm{HS}^{-}$, and $\mathrm{S}^{2-}$ practically all occur as aqueous hydrogen sulfide $\left(\mathrm{HS}^{-}\right)$in the acidic range, they react with dimethyl-p-phenylenediamine and $\mathrm{Fe}(\mathrm{III})$ ions 
Table 1 Experimental setting and amount of used additives (GFH or $40 \% \mathrm{FeCl}_{3}$ solution)

\begin{tabular}{lll}
\hline Experimental setting & $\begin{array}{l}\text { Type and amount of additive per volume } \\
\text { thermal water }\end{array}$ & $\begin{array}{c}\text { Filtered } \\
\text { and monitored }\end{array}$ \\
\hline A_0 (no compressor) & 0 & - \\
A_1 & $500 \mathrm{~mL} \mathrm{GFH}$ in $300 \mathrm{~L}(0.85 \mathrm{~g} / \mathrm{L})$ & no \\
B_0 (no compressor) & 0 & - \\
B_1 & $500 \mathrm{~mL} \mathrm{GFH}$ in $300 \mathrm{~L}(0.85 \mathrm{~g} / \mathrm{L})$ & yes \\
C_0_1 (no compressor) & 0 & - \\
C_0_2 (compressor) & 0 & - \\
C_1_1 (compressor) & $55 \mathrm{ml} \mathrm{GFH} \mathrm{in} 300 \mathrm{~L}(0.094 \mathrm{~g} / \mathrm{L})$ & yes \\
C_1_2 (compressor) & $55 \mathrm{ml} \mathrm{GFH} \mathrm{in} 300 \mathrm{~L}($ total $0.187 \mathrm{~g} / \mathrm{L})$ & yes \\
D_0 (compressor) & 0 & yes \\
D_1 & $50 \mathrm{~mL} \mathrm{GFH} \mathrm{in} 400 \mathrm{~L}(0.06 \mathrm{~g} / \mathrm{L})$ & yes \\
E_0 (compressor) & 0 & yes \\
E_1 & $75 \mathrm{~mL} \mathrm{FeCl}$ in $400 \mathrm{~L}$ & yes \\
\hline
\end{tabular}

to methylene blue (Cline, 1969). This colored complex was measured at a wavelength of $665 \mathrm{~nm}$. The maximum dilution of the thermal water was 1:20 and the measurement accuracy is $\pm 0.017 \mathrm{mg} / \mathrm{l}$.

Fluid physical parameters (EC, $\mathrm{pH}, \mathrm{Eh}, \mathrm{DO})$ were measured in a flow-through cell directly at the outflow of the IBC container by WTW electrodes (DO amperometrically, the $\mathrm{pH}$ by a glass- and Eh by an $\mathrm{Ag} / \mathrm{AgCl}$ probe). Data (not temperature corrected) were recorded every few minutes thus giving punctual information. The fluid monitoring system FluMo, installed after the HydroGeoFilt, measures the same physicochemical parameters also in flow-through cells but collects data every minute and stores them automatically, thus giving a much higher accuracy. The used electrodes for $\mathrm{pH}$ and Eh (Endress \& Hauser) are temperature compensated.

To estimate the grain sizes of particles before and after the reaction of the additives with the thermal brine, three filters were connected with a tube to each other in a row (cascade filter, Fig. 2) and about $500 \mathrm{ml}$ brine with either $\mathrm{FeCl}_{3}$ or $\mathrm{GFH}$ additive was injected with a syringe into the line. Visually it was estimated after which filtration step the particles were removed. Altogether four of those tests were performed on site.

\section{Laboratory analytics}

Cation and anion concentrations were measured with a Thermo Sientific Dionex ion chromatography system and evaluated by the Dionex Chromeleon 6.8 software. The organic content was characterized in terms of organic acids in four samples by ion chromatography and in terms of size distribution of the molecules by liquid

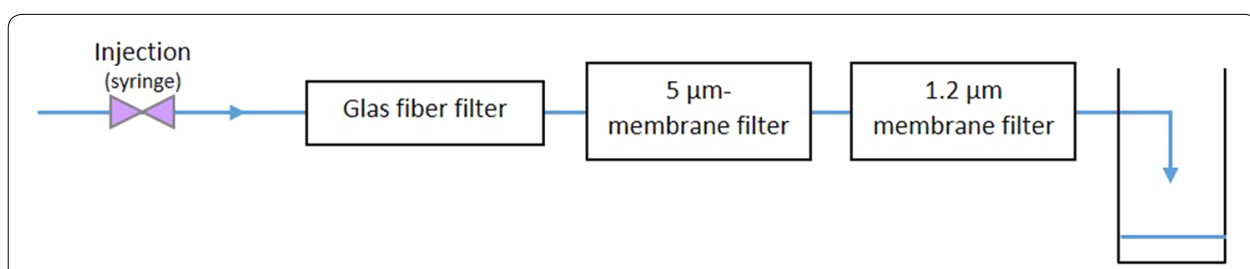

Fig. 2 Scheme of cascade filtration to estimate the grain size distribution of the solid phase in the system 
Table 2 Selected samples for solid phase analysis (XRD and SEM)

\begin{tabular}{llll}
\hline $\mathbf{N r}$ & Experiment description & XRD & SEM \\
\hline 1 & Experiment $\mathrm{D}$; filter backwash $5+10 \mu \mathrm{m}$ & $\mathrm{Y}$ & $\mathrm{Y}$ \\
8 & Filter test 2 $\left(\mathrm{FeCl}_{3}\right) ; 5$ - $\mu \mathrm{m}$ filter & $\mathrm{Y}$ & $\mathrm{Y}$ \\
9 & Experiment $\mathrm{E}_{\text {; filter test } 3 ; 5 \mu \mathrm{m} \mathrm{FeCl}} ; 100 \mu \mathrm{L} ; 400 \mathrm{~mL}$ brine & $\mathrm{Y}$ & $\mathrm{N}$ \\
10 & Filter test 4 $\left(\mathrm{FeCl}_{3}\right) ; 1.2 \mu \mathrm{m}$; taken from IBC & $\mathrm{N}$ & $\mathrm{N}$ \\
11 & Filter test 4 $\left(\mathrm{FeCl}_{3}\right) ; 5$ - $\mu$ m filter; taken from IBC & $\mathrm{Y}$ & $\mathrm{Y}$ \\
2 & Experiment $\mathrm{E}_{\text {; filter backwash } 10 \mu \mathrm{m}}$ & $\mathrm{Y}$ & $\mathrm{Y}$ \\
3 & Experiment $\mathrm{E}$ filter backwash $5 \mu \mathrm{m}$ & $\mathrm{Y}$ & $\mathrm{Y}$ \\
12 & Pre-experiment $\mathrm{FeCl}_{3}: \mathrm{TH} 1: 10,000 \mathrm{pH}=6.9$ & $\mathrm{~N}$ \\
\hline
\end{tabular}

Table 3 Background values of physicochemical parameters of the thermal water (mean values and standard deviation of five samples collected over a period of $17 \mathrm{~min}$ )

\begin{tabular}{llllll}
\hline & $\mathbf{p H}$ & $\mathrm{EC}(\mathbf{m S} / \mathbf{c m})$ & $\mathrm{Eh}(\mathbf{m V})$ & $\mathrm{DO}(\mathbf{m g} / \mathbf{L})$ & $\mathbf{T}\left({ }^{\circ} \mathbf{C}\right)$ \\
\hline Mean value thermal water & 6.51 & 4.80 & -372 & 0.17 & 49.80 \\
Standard deviation & 0.005 & 0.000 & 3.71 & 0.027 & 0.173 \\
\hline
\end{tabular}

chromatography organic carbon detection (LC-OCD). Two of the selected samples were collected in untreated water directly from the well, one was collected after treatment with GFH (experiment C) and one after treatment with $\mathrm{FeCl}_{3}$ (experiment D).

Precipitates as sampled from the filters were analyzed for their mineral composition by X-ray diffraction (XRD; with a $\mathrm{Cu} K \alpha 1$ radiation source and primary monochromator; Table 2). Diffractograms were semi-quantitatively evaluated by the software EVA. Scanning electron microscopy (SEM) with a beam current acceleration of $20 \mathrm{kV}$, and a maximum aperture of $120 \mu \mathrm{m}$ was applied on four of the filter residue samples. On selected image spots, the material composition was semi-quantitatively characterized by energy dispersive X-ray (EDX), using the same accelerating voltage.

\section{Results}

\section{Pre-experiments}

\section{Pre-experiment I}

The thermal water without addition of any additives has a temperature of about $50{ }^{\circ} \mathrm{C}$ and is of neutral $\mathrm{pH}$ value (6.5). The EC is relatively low $(4.8 \mathrm{mS} / \mathrm{cm})$ but above freshwater and redox conditions are strongly reducing $(-372 \mathrm{mV}$; Table 2$)$. Altogether, these values were relatively stable over time $(17 \mathrm{~min})$ as confirmed by their low standard deviations obtained from five measurements (Table 3).

\section{Pre-experiment II}

After adding some GFH to the thermal water in a beaker, the sulfide content decreased from 30 to almost $0 \mathrm{mg} / \mathrm{L}$ in less than $20 \mathrm{~min}$ (Fig. 3). Assuming a first-order reaction 


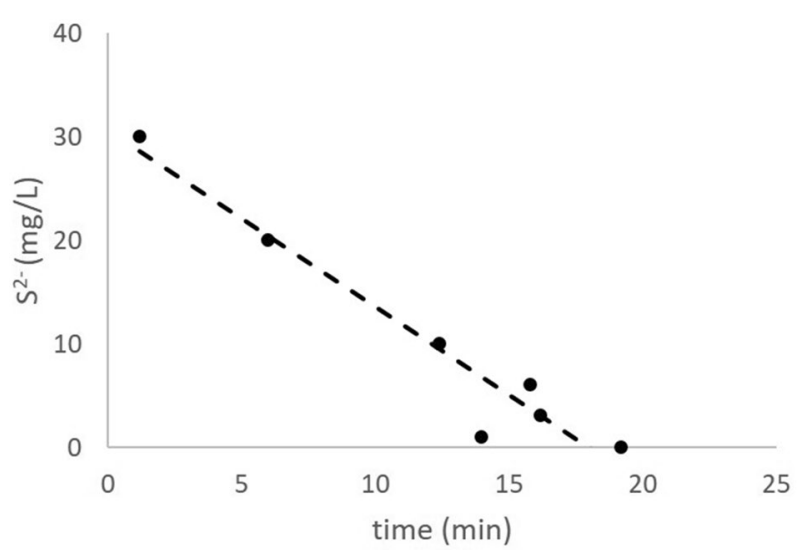

Fig. 3 Sulfide concentration measured over time after GFH was added into a glass beaker filled with fresh thermal water $(0.64 \mathrm{~g} / \mathrm{L})$

Table 4 Pre-experiment III: mixing a $40 \% \mathrm{FeCl}_{3}$ solution with thermal water in different ratios

\begin{tabular}{lllll}
\hline Mixing ratio & $\mathrm{FeCl}_{\mathbf{3}}$ added $(\mathbf{m g} / \mathbf{L})$ & $\mathbf{p H}$ & Suspension color & $\begin{array}{l}\text { Hydrogen } \\
\text { sulfide } \\
\text { (mg/L) }\end{array}$ \\
\hline $1: 100$ & 2000 & 1.3 & Red & $\mathrm{nm}$ \\
$1: 1000$ & 200 & 2.8 & & $\mathrm{~nm}$ \\
$1: 10,000$ & $20(0.4 \mathrm{mM})$ & 6.9 & Black & $\mathrm{nm}$ \\
$1: 4000$ & 50 & 6.1 & & 2.2 \\
$1: 8000$ & 25 & 6.17 & & 5 \\
\hline
\end{tabular}

$\left(\mathrm{Fe}^{3+}+\mathrm{S}^{2-} \leftrightarrow \mathrm{FeS}\right)$, the rate constant, in a $0.78 \mathrm{~g} / \mathrm{L}$ suspension as given from the slope, is $1.7 \mathrm{mg}$ sulfide consumption per minute (Fig. 3).

\section{Pre-experiment III}

Dilutions of $\mathrm{FeCl}_{3}$ solution (40\%) with fresh thermal water and with aged thermal water (sulfide already removed) were mixed in different ratios, and the $\mathrm{pH}$ and the sulfide concentration (for $\mathrm{pH}>6$ ) were measured afterward (Table 4). In the mixtures of 400 - and $100-\mathrm{ml}$ thermal water with $50 \mu \mathrm{L}$ and $100 \mu \mathrm{L}$, respectively, $\mathrm{FeCl}_{3}$, the solution turned immediately black $_{3}$ (Table 4 ). The solutions became all clear again after filtration $(0.45 \mu \mathrm{m})$.

To oxidize a sulfide concentration of about $1 \mathrm{mM}(32 \mathrm{mg} / \mathrm{L})$, as measured in the thermal water, either 1 or $0.5 \mathrm{mM}$ Fe would be required (calculations according to Eqs. 2 and 3). Based on the dilution test and this calculation, it was decided to add for the actual experiment $75 \mathrm{ml}$ of the $\mathrm{FeCl}_{3}$ solution into the IBC container with $400 \mathrm{~L}$ thermal water to obtain a mixing ratio of 1:5333 corresponding to $37.5 \mathrm{mg} \mathrm{Fe} / \mathrm{L}$ and a $\mathrm{pH}$ of 6.1 . 


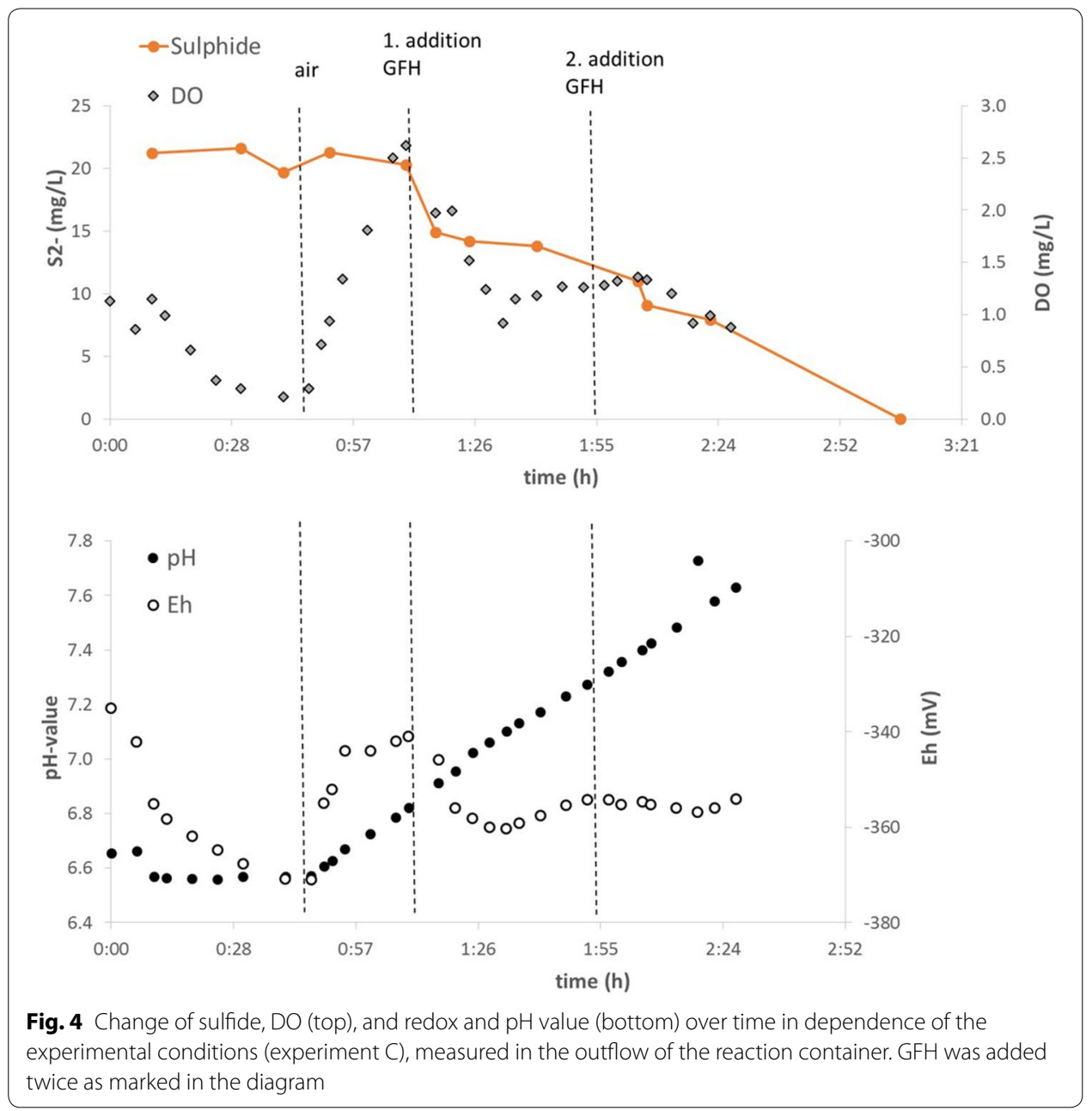

\section{Main experiments}

\section{In situ measurements}

Addition of GFH to thermal water When circulating fluid pumped from the well through the IBC container (e.g., experiment $\mathrm{C}$ ), the $\mathrm{pH}$ remained relatively stable (about 6.65) while redox and DO decreased slightly. After switching on the compressor, more air oxygen entered the water and redox, $\mathrm{pH}$, and oxygen increased (Fig. 4). Before addition of $\mathrm{GFH}$, the oxygen content in the water increased but the sulfide content remained stable indicating that oxygen alone had little impact on the sulfide oxidation (Fig. 4). The addition of GFH $(0.125 \mathrm{~g} / \mathrm{L} \mathrm{Fe})$ resulted in a decrease of the redox, DO, and sulfide (from 21 to $14 \mathrm{mg} / \mathrm{L}$ ), while the $\mathrm{pH}$ continued to increase (up to $\mathrm{pH}$ 7.6). When the sulfide concentration stabilized at around $14 \mathrm{mg} / \mathrm{L}, \mathrm{DO}$ and redox slightly increased again. At this point, the same amount of GFH was added again and the sulfide decreased further to $7.9 \mathrm{mg} / \mathrm{L}$. After another $40 \mathrm{~min}$, a last sample was collected that showed a sulfide concentration below the detection limit (Fig. 4).

Similarly, during experiment D, GFH was added to the IBC container. This time the HydroGeoFilt and afterward the fluid monitoring system were connected to the fluid 
loop (Fig. 1). Again it was found that the $\mathrm{pH}$ value constantly increased as soon as the air compressor was switched on (from 6.9 to 7.4), whereas the redox was relatively constant between -339 and $-344 \mathrm{mV}$. Once GFH was added to the system, sulfide started decreasing, a process that took about $30 \mathrm{~min}$ until GFH was fully removed.

Before GFH addition, the fluid monitoring device started measuring the fluid properties of the thermal water. Complementarily to measurements in the container, the $\mathrm{pH}$ increased (from 7.5 to 7.9 ) and the redox remained constant ( $-337 \mathrm{mV}$ ). When GFH was added, the fluid monitoring with FluMo had to be stopped and was switched on again after $14 \mathrm{~min}$ (Fig. 5). During this time, the $\mathrm{pH}$ and redox first increased and decreased again until both values stabilized after around $40 \mathrm{~min}$. This is about the same time it took until all sulfide was removed from the system. The monitored parameters ( $\mathrm{pH}$ and $\mathrm{Eh}$ ) proved to be very sensitive, as obvious by glitches in both curves, when the filter candles were exchanged (Fig. 5).

Addition of $\mathrm{FeCl}_{3}$ solution The addition of concentrated $\mathrm{FeCl}_{3}$ solution into the IBC container (Experiment E; $0.7 \mathrm{mM}$ ) resulted in an immediate color change of the fluid (from colorless to black) and the complete removal of sulfide after 17 min of reaction in the IBC container (Fig. 6). Over the next $30 \mathrm{~min}$, the color changed from a homogenous black solution via grey to orange (Fig. 8) and the pH and Eh increased constantly (Fig. 7). Similarly as compared to the experiments with GFH, the $\mathrm{pH}$ value further increased even after all sulfide was consumed. The redox increased more strongly (up to $-50 \mathrm{mV}$ ) both in the IBC container (Fig. 6) and when measured after filtering with FluMo (Fig. 8).

When measuring downstream of the filter, the redox increased over time after addition of $\mathrm{FeCl}_{3}$ solution to the thermal water (Fig. 8). After all sulfide was removed from the solution, the redox dropped and only afterward it rose again (Fig. 8). The comparison of the redox values between solutions with added $\mathrm{GFH}$ and $\mathrm{FeCl}_{3}$ showed in both

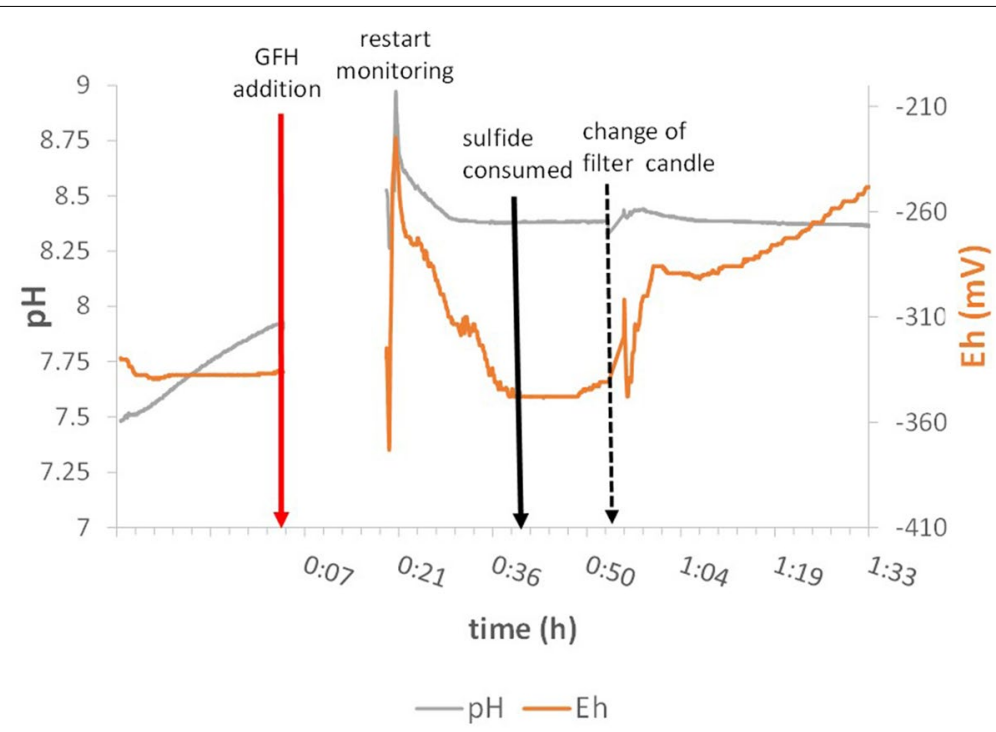

Fig. $5 \mathrm{pH}$ and Eh monitoring by the fluid monitoring device FluMo during experiment $\mathrm{D}$ after the filter 


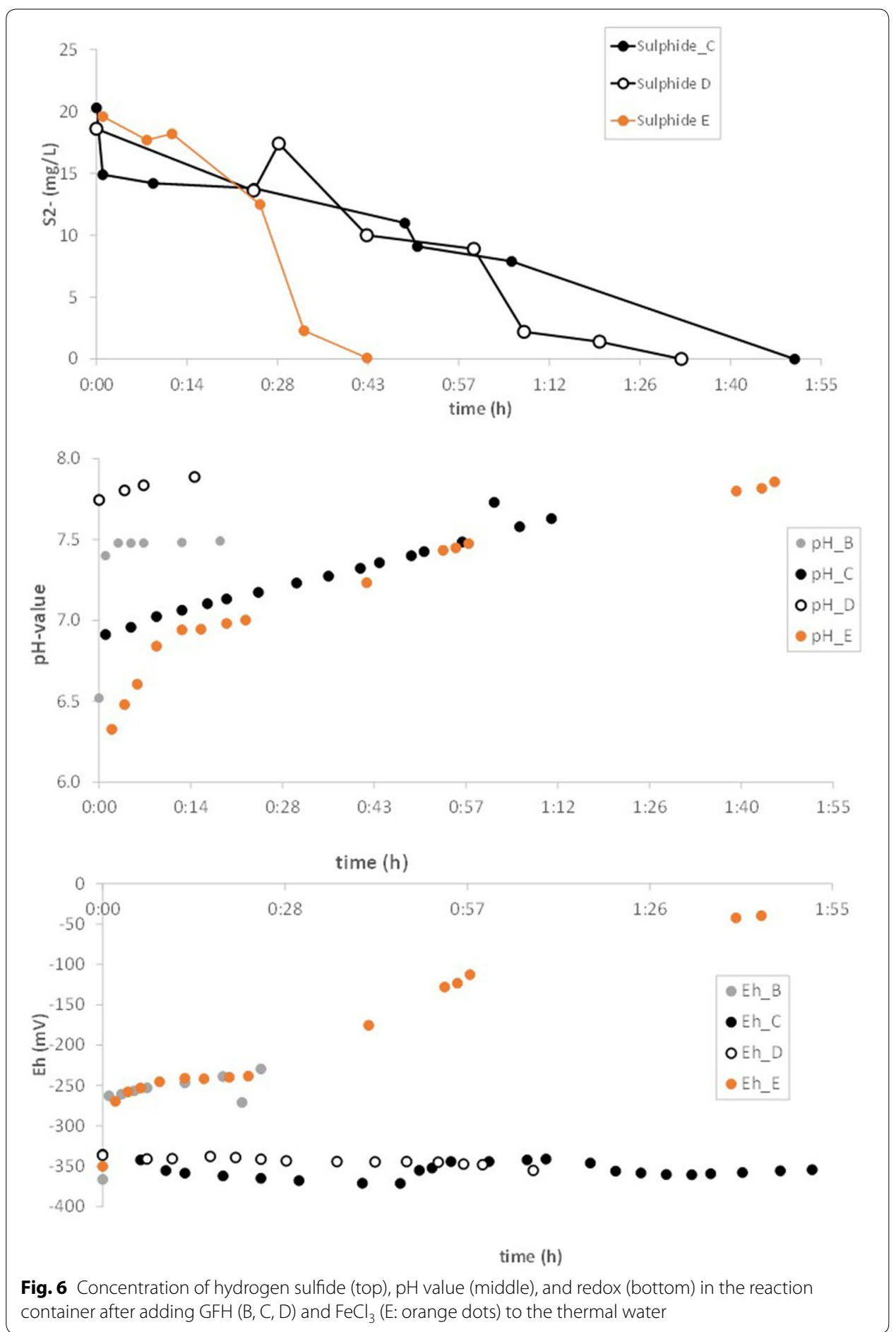

cases high variations during the actual redox reaction. Altogether, the conditions stabilized faster when $\mathrm{FeCl}_{3}$ was added (Fig. 8). 


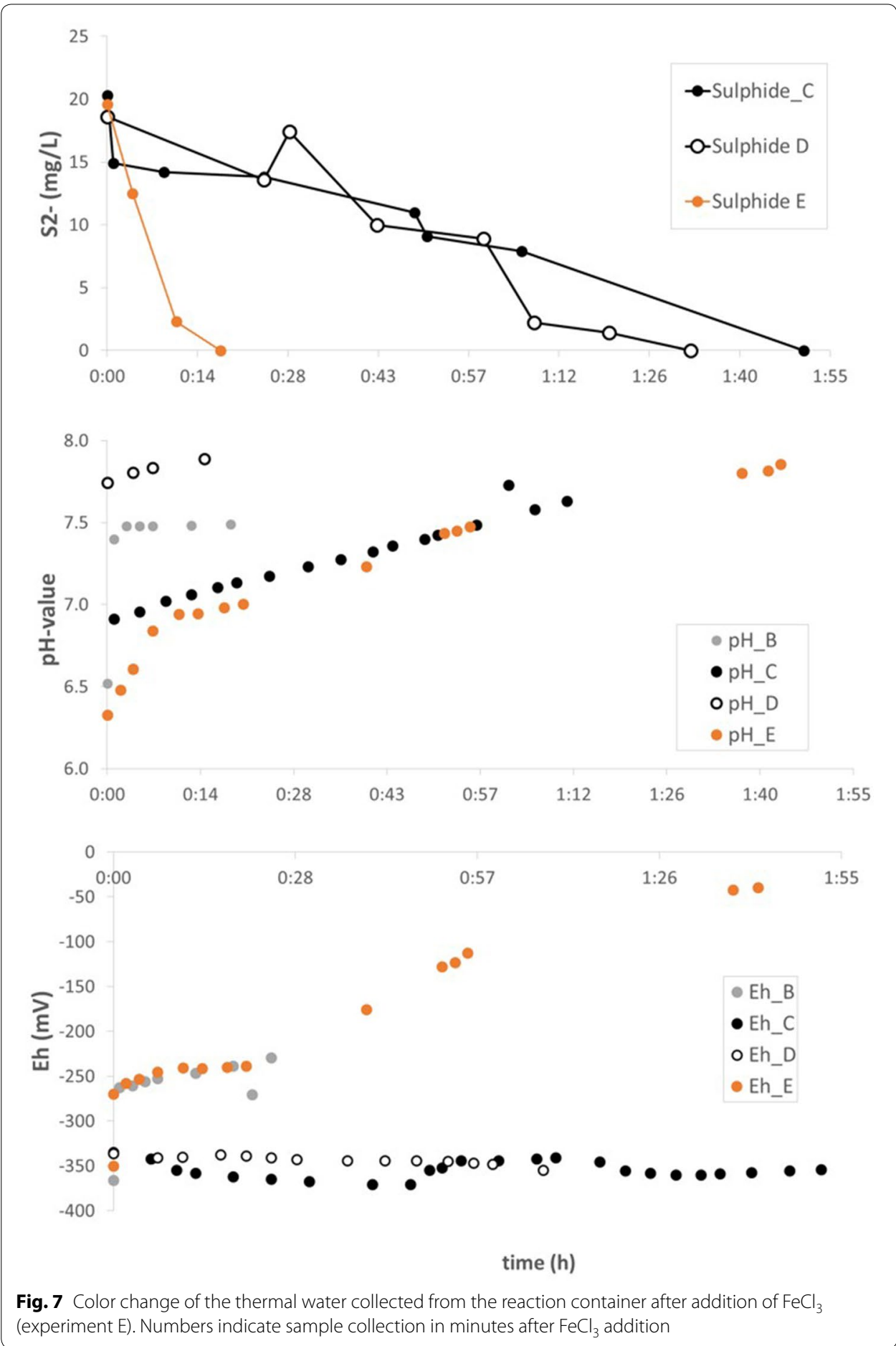

\section{Lab analysis: water composition}

Results of the elemental composition of selected water samples are given in Table 5 . The main anions of the thermal water are chloride $(830-880 \mathrm{mg} / \mathrm{L})$ and sulfate $(1600-$ $1200 \mathrm{mg} / \mathrm{L}$ ), which both hardly changed in concentration in dependence of the type and duration of the experiment. Since the sulfate concentration did not show any correlation 


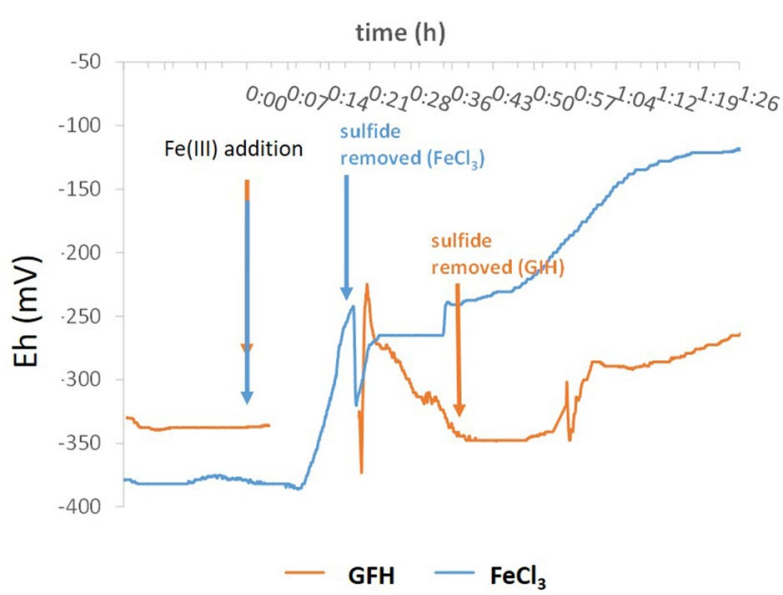

Fig. 8 Change of Eh as measured by the fluid monitoring device FluMo after filtration of the thermal water in experiment $\mathrm{D}$ (addition of $\mathrm{GFH}$ ) and experiment $\mathrm{E}$ (addition of $\mathrm{FeCl}_{3}$ )

Table 5 Main cations and anion of selected water samples during experiments $C$, D and $E$ (mg/L)

\begin{tabular}{|c|c|c|c|c|c|c|c|c|c|}
\hline Sample & Treatment & $\mathrm{Na}^{+}$ & $\mathrm{K}^{+}$ & $\mathrm{Ca}^{2+}$ & $\mathrm{Mg}^{2+}$ & $\mathrm{HCO}_{3}{ }^{-}$ & $\mathrm{Cl}^{-}$ & $\mathrm{SO}_{4}{ }^{2-}$ & $\mathrm{Fe}$ \\
\hline Water & Filtered & 520 & 23 & 430 & 130 & 172 & 860 & 1400 & $<0.02$ \\
\hline Water & Unfiltered & 510 & 22 & 420 & 130 & 233 & 800 & 1300 & $<0.02$ \\
\hline \multirow[t]{4}{*}{ Exp. C } & Before addition & 510 & 22 & 430 & 120 & $\mathrm{~nm}$ & $\mathrm{~nm}$ & 1500 & $<0.02$ \\
\hline & After GFH_1 & 510 & 22 & 430 & 120 & $\mathrm{~nm}$ & $\mathrm{~nm}$ & 1500 & 4.5 \\
\hline & After GFH_2 & 510 & 21 & 420 & 120 & $\mathrm{~nm}$ & $\mathrm{~nm}$ & 1500 & 10.5 \\
\hline & After GFH_2 & 510 & 22 & 430 & 120 & $\mathrm{~nm}$ & $\mathrm{~nm}$ & 1500 & $<0.02$ \\
\hline \multirow[t]{6}{*}{ Exp. D } & Before addition & 480 & 21 & 400 & 120 & $\mathrm{~nm}$ & $\mathrm{~nm}$ & 1500 & $<0.02$ \\
\hline & Before addition & 480 & 20 & 400 & 110 & $\mathrm{~nm}$ & $\mathrm{~nm}$ & 1400 & $<0.02$ \\
\hline & After GFH & 480 & 20 & 400 & 110 & $\mathrm{~nm}$ & $\mathrm{~nm}$ & 1400 & $<0.02$ \\
\hline & After GFH & 450 & 18 & 350 & 100 & $\mathrm{~nm}$ & $\mathrm{~nm}$ & 1200 & $<0.02$ \\
\hline & After GFH & 460 & 19 & 370 & 110 & $\mathrm{~nm}$ & $\mathrm{~nm}$ & 1300 & $<0.02$ \\
\hline & Before addition & 510 & 22 & 430 & 120 & $\mathrm{~nm}$ & $\mathrm{~nm}$ & 1500 & $<0.02$ \\
\hline \multirow[t]{4}{*}{ Exp. E } & After $\mathrm{FeCl}_{3}$ & 530 & 21 & 420 & 120 & $\mathrm{~nm}$ & $\mathrm{~nm}$ & 1400 & 6.7 \\
\hline & After $\mathrm{FeCl}_{3}$ & 510 & 22 & 420 & 120 & $\mathrm{~nm}$ & $\mathrm{~nm}$ & 1500 & $<0.02$ \\
\hline & After $\mathrm{FeCl}_{3}$ & 510 & 22 & 430 & 120 & $\mathrm{~nm}$ & $\mathrm{~nm}$ & 1400 & $<0.02$ \\
\hline & After $\mathrm{FeCl}_{3}$ & 510 & 21 & 420 & 120 & $\mathrm{~nm}$ & $\mathrm{~nm}$ & 1400 & 2.186 \\
\hline
\end{tabular}

$n m$ not measured

with the amount and type of iron additive, any potentially by Fe(III) reduction formed sulfate was still in the same order of magnitude as the natural sulfate variability of the brine. Similarly, $\mathrm{Mg}, \mathrm{Ca}$, and $\mathrm{K}$ concentrations showed no treatment-dependent variation being in the range of $100-120 \mathrm{mg} / \mathrm{L}, 400-430 \mathrm{mg} / \mathrm{L}$, and $20-22 \mathrm{mg} / \mathrm{L}$, respectively (Table 5). Manganese was below detection limit and the alkalinity ranged between 14.6 and $15.6 \mathrm{mM}$. Solely the iron concentration varied more strongly between below detection limit $(<0.02 \mathrm{mg} / \mathrm{L})$ as measured in most samples and a maximum of $10.5 \mathrm{mg} / \mathrm{L}$ (Table 5).

The anion thiosulfate $\left(\mathrm{S}_{2} \mathrm{O}_{3}{ }^{2-}\right)$ was measured in two samples of the untreated thermal water $(24-30 \mathrm{mg} / \mathrm{L})$ and in two samples of $\mathrm{GFH}$ and $\mathrm{FeCl}_{3}$ treated samples. A 
clear decrease of thiosulfate was measured after the addition of both additives. When using GFH still $4.6 \mathrm{mg} / \mathrm{L}$ thiosulfate was remaining in the solution, whereas the removal was almost complete after adding $\mathrm{FeCl}_{3}(0.8 \mathrm{mg} / \mathrm{L}$ thiosulfate). Analysis of the organic composition of the thermal water indicated that no measurable amounts of organic acids were present in the samples. The organic carbon content ranged between 0.2 and $0.4 \mathrm{mg} / \mathrm{L}$ in all samples. The addition of $\mathrm{FeCl}_{3}$ or $\mathrm{GFH}$ showed no evident effect on the organic carbon content.

\section{Lab analysis: solid phase}

Selected samples from either the backwash of the HydroGeoFilt or from the cascade filter tests were analyzed by XRD and/or SEM (Table 2). The cascade filter test of suspensions containing GFH indicated that particles were relatively large and all visible particles were retained at a filter size of $1.2 \mu \mathrm{m}$. Indeed, those water samples were also clear when filtered by the HydroGeoFilt using mesh size $<10 \mu \mathrm{m}$. However, when applying the $\mathrm{FeCl}_{3}$ method, formed particles were smaller than the smallest used filter size (HydroGeoFilt: $<5 \mu \mathrm{m}$; cascade filter $<1.2 \mu \mathrm{m}$ ). By filtration with a $0.45-\mu \mathrm{m}$ syringe filter, also those water samples became clear.

XRD analysis of the filter residues obtained after the reaction of $\mathrm{FeCl}_{3}$ with thermal water revealed the presence of weakly crystalline substances as obvious from the high background noise (Fig. 9). All measured samples showed a similar XRD pattern and the identification of the few peaks indicated the presence of pyrrothite (Fig. 9). No interpretation was possible for the other peaks.

Scanning electron micrographs of the formed particles collected from the filters showed few samples that exhibited clear crystalline structures. By application of EDX predominantly $\mathrm{SO}_{3}, \mathrm{Fe}_{2} \mathrm{O}_{3}, \mathrm{CaO}$, and $\mathrm{SiO}_{2}$ were detected. The few crystalline particles could be attributed to gypsum or anhydrite (consisting mainly $\mathrm{CaO}$ and $\mathrm{SO}_{4}$ ) indicating that by drying (water evaporation) $\mathrm{CaSO}_{4}$ saturation was reached. Samples from

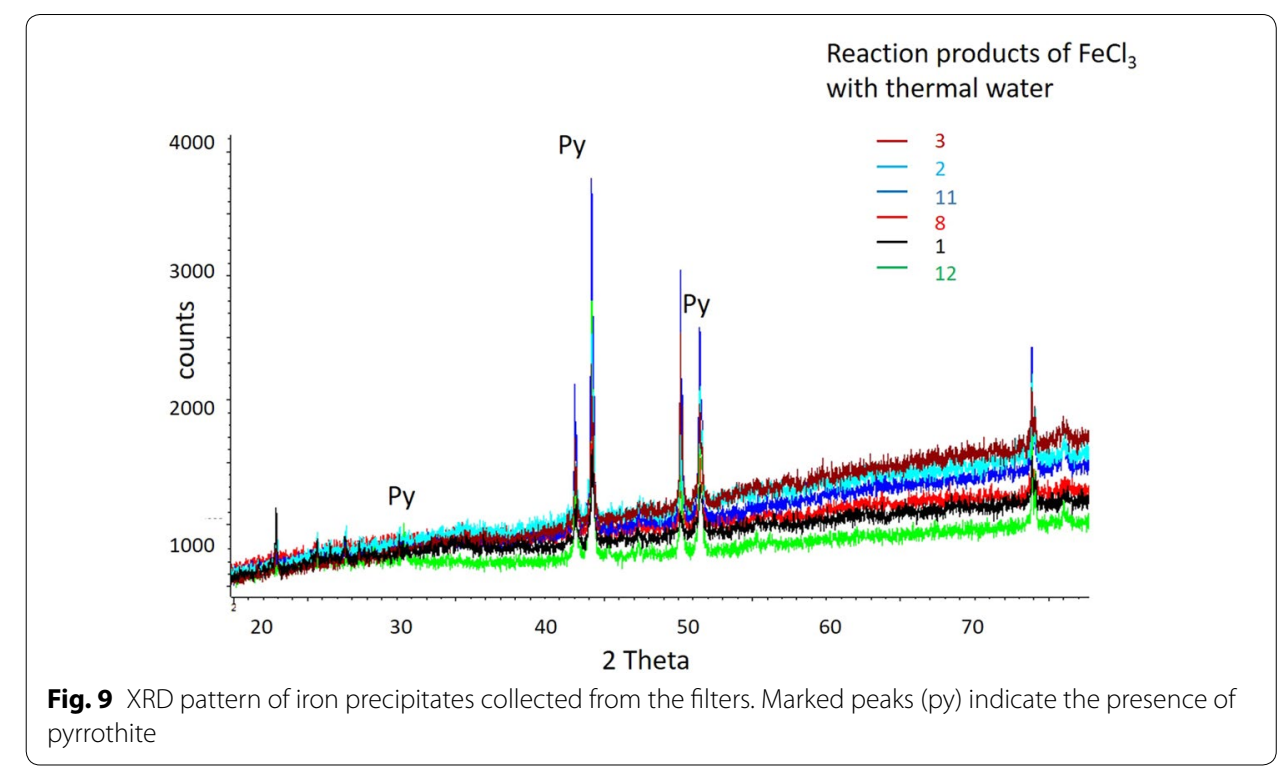




\begin{tabular}{|r|l|l|l|l|l|}
\hline $\begin{array}{r}\text { Filter residue } \\
\text { (backwash, }\end{array}$ & & & & & \\
\hline
\end{tabular}

Fig. 10 SEM pictures of three samples (Table 2) together with the main elemental composition as obtained by EDX measurements

experiment D consisted to similar ratios out of the elements $\mathrm{S}$ and Fe. In experiment E, however, the Fe fraction was much more variable and also higher (up to $80-90 \%$ $\mathrm{Fe}_{2} \mathrm{O}_{3}$; Fig. 10).

\section{Discussion}

Processes in the reaction container

\section{Sulfur speciation}

Although the geochemical redox system seems relatively simple with just three elements being involved in the reactions $(\mathrm{Fe}, \mathrm{O}, \mathrm{S})$, various species with several redox states, especially those of sulfur, have to be considered to form, party as metastable phases in the reaction container. To get an idea, which species are most likely to form, equilibrium calculations were performed with the Hydra/Medusa code (Puigdomenech 2004), although this program does not consider metastable phases such as thiosulfate. In the pure sulfur water redox system (without iron), at given $\mathrm{pH}$ and redox conditions, an oxidation of hydrogen sulfide to sulfate seems likely (Fig. 11), whereas elemental sulfur most likely does not form. In the presence of $\mathrm{Fe}$, with increasing redox, the species $\mathrm{FeS}, \mathrm{FeS}_{2}$ and $\mathrm{SO}_{4}$ are stable. A further increase of the redox to 

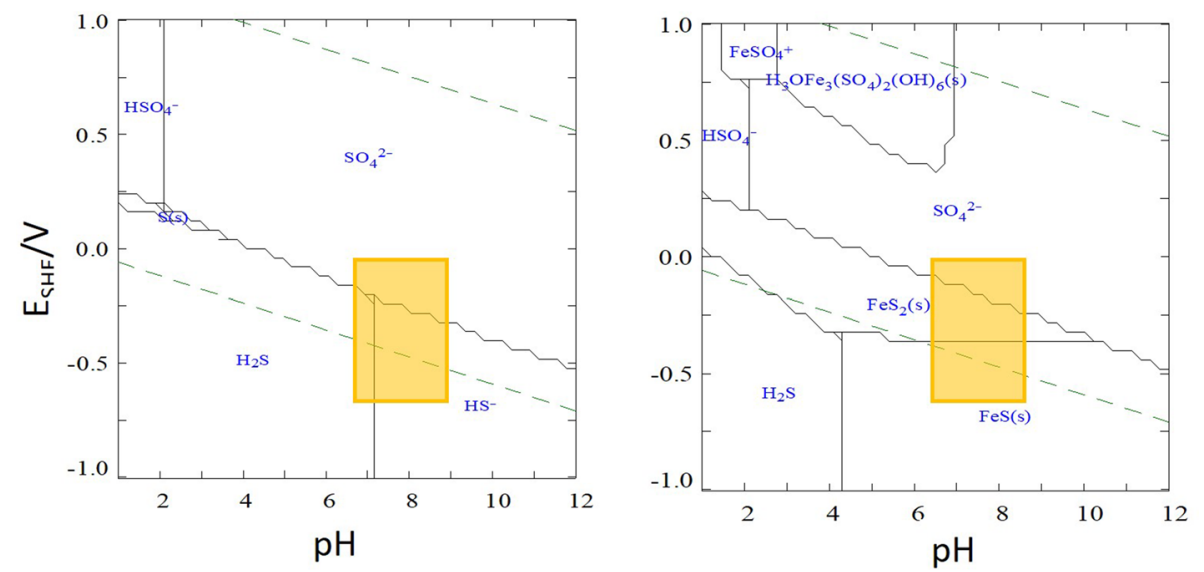

Fig. 11 Predominance diagrams as calculated by the code Hydra/Medusa code at room temperature (Puigdomenech, 2004). Left for the sulfur redox system and right for the iron-sulfur redox system.

Concentrations of Fe and $\mathrm{S}$ are each $1 \mathrm{mM}$. Areas of relevance during the experiments are marked in yellow. The redox Eh is given in $\mathrm{V}$ referred to the standard hydrogen probe at $25^{\circ} \mathrm{C}$

about $30 \mathrm{mV}$ would have resulted eventually in the formation of a ferric iron oxyhydroxysulfate (Fig. 11).

The system becomes even more complicated since not only sulfate $\left(\mathrm{SO}_{4}{ }^{2-}\right)$ and hydrogen sulfide $\left(\mathrm{HS}^{-}, \mathrm{H}_{2} \mathrm{~S}\right)$ occur, but also thiosulfate $\left(\mathrm{S}_{2} \mathrm{O}_{3}{ }^{2-}\right.$; redox state of $\left.\mathrm{S}:-2\right)$ was measured, which was highest in the untreated thermal water samples evidencing its natural occurrence in the formation water. Thiosulfate decreased strongly after the treatment with $\mathrm{Fe}(\mathrm{III})$ (down to $4.6 \mathrm{mg} / \mathrm{L}$ when adding $\mathrm{GFH}$ and down to $0.8 \mathrm{~g} / \mathrm{L}$ when adding $\mathrm{FeCl}_{3}$ ) it can be assumed that it reacted with $\mathrm{Fe}^{3+}$ to form the metastable aqueous complex ferrous tetrathionate $\mathrm{FeS}_{4} \mathrm{O}_{6}$ (Eq. 8; Druschel et al. 2003).

$$
2 \mathrm{~S}_{2} \mathrm{O}_{3}^{2-}+2 \mathrm{Fe}^{3+} \rightarrow 2 \mathrm{Fe}^{2+}+\mathrm{S}_{4} \mathrm{O}_{6}^{2-}
$$

This product readily decomposes, evolving sulfur dioxide and elemental sulfur (Eq. 9):

$$
\mathrm{FeS}_{4} \mathrm{O}_{6} \rightarrow \mathrm{FeSO}_{4}+\mathrm{SO}_{2}+2 \mathrm{~S}
$$

Although it was not possible within this study to verify all these poly-sulfur species in the water and gas, their presence and interaction in the redox processes are very likely.

\section{Consumption of protons and redox changes}

In all experiments (both, with $\mathrm{FeCl}_{3}$ and with $\mathrm{GFH}$ ), the $\mathrm{pH}$ in the IBC container went up over the entire period of the experiments starting with the moment, when the compressor was switched on to pump air bubbles into the water (e.g., from 6.3 to 7.8, Fig. 4). This increase can be explained by a shift in the equilibrium between gaseous and dissolved $\mathrm{H}_{2} \mathrm{~S}$. The purging removed more $\mathrm{H}_{2} \mathrm{~S}$ and therefore more protons from the water and the $\mathrm{pH}$ slightly increased. This continued even after all hydrogen sulfide was removed. In the GFH suspension the $\mathrm{pH}$ even increased further to nearly 9 and decreased afterward until stabilizing at a $\mathrm{pH}$ of 8.5. Based on these results, a $\mathrm{pH}$ stabilization indicates a completion of the reaction although hydrogen sulfide was consumed already at an earlier stage. 
The redox value did not change significantly when adding GFH to the thermal water, but increased strongly after addition of $\mathrm{FeCl}_{3}$ (Figs. 5, 7). Clearly, this strong increase of the Eh value was not only due to dissolution of air oxygen into the thermal water but also due to oxidation of both, sulfide and thiosulfate, by reduction of $\mathrm{Fe}(\mathrm{III})$ during the formation of the black FeS species (Eq. 2). This immediate reaction strongly consumed electrons. After the sulfide was removed from the system (experiment E), the Eh decreased again but started to increase afterward. Simultaneously, the black FeS oxidized to form an orange iron(III) hydroxide. The sulfide sulfur would also be oxidized but from the present data it cannot be concluded to which redox state. Clearly, it was not thiosulfate since this anion also "disappeared" during the reaction. An oxidation to sulfate might be possible but the sulfate concentration was generally very high and slightly variable in the system (between 1200 and $1500 \mathrm{mg} / \mathrm{L}$; Table 5). Assuming about $1 \mathrm{mmol} \mathrm{H}_{2} \mathrm{~S}$ in the thermal water $(32 \mathrm{mg} / \mathrm{L})$ that could be oxidized, also $1 \mathrm{mmol}$ sulfate $(96 \mathrm{mg} / \mathrm{L})$ could have been formed at maximum by reaction with $\mathrm{Fe}(\mathrm{III})$, which is within the natural variability of sulfate. Occasionally, high Fe concentrations $(0-10 \mathrm{mg} / \mathrm{L})$ can be attributed to redox reactions since they occurred only after addition of Fe (Table 5).

\section{Formation of solid phases and surface reactions}

The formed sulfate or other sulfur species could also be retained on solid phases either by adsorption on the surface of the freshly formed iron(III) hydroxides or it could be incorporated into iron sulfate compounds as well as into gypsum or anhydrite. Indeed, SEM measurements indicated the formation of $\mathrm{CaSO}_{4}$ crystals in filter residue samples from the HydroGeoFilt of experiment $\mathrm{D}$ and $\mathrm{E}$ (Fig. 10). However, the $\mathrm{CaSO}_{4}$ precipitation was probably an effect of evaporation during drying because, as indicated by calculations with PhreeqC (llnl database), gypsum saturation was not reached for the experimental conditions of this study.

Characterization of the formed solid phases from the $\mathrm{FeCl}_{3}$ solutions as indicated by XRD indicated that pyrrothite (FeS) and another, unidentifiable species (unknown XRD peaks) together with weakly crystalline/amorphous iron hydroxides had formed (Fig. 9). Similar results were obtained by Firer et al. (2008), who determined both by equilibrium modeling (MINEQL + ) and experimentally that the precipitation product of ferrous salts and hydrogen sulfide was FeS under all their experimental conditions tested. In the same study, it was found that sulfate was always the reaction product when adding ferric iron. Therefore, as a metastable phase, also the formation of the oxyhydroxyulphate mineral schwertmannite seems possible, because it is known to precipitate rapidly upon oxidation of Fe(II) sulfate-containing solutions (Regenspurg et al. 2004). Schwertmannite typically forms at acidic $(<\mathrm{pH} 4.0)$ conditions, whereas the $\mathrm{pH}$ range of the solutions was generally neutral. However, many solid, metastable and weakly crystalline phases that might have formed in low concentrations are very difficult to detect by most mineralogical methods. For the quantification of those species different methods such as infrared spectroscopy or sequential extraction should be carried out that are suitable for determining also solid iron sulfide phases such as pyrite (Müller et al. 2017). 


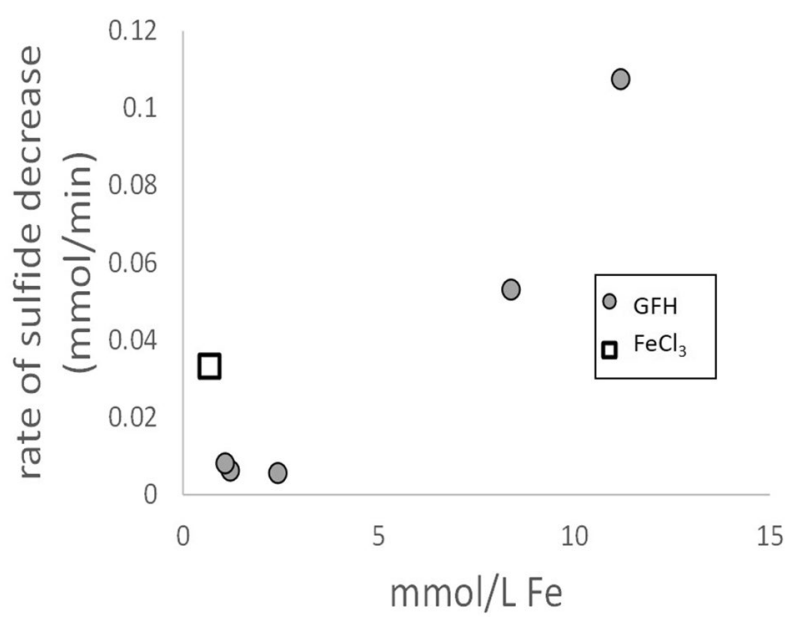

Fig. 12 Rate of hydrogen sulfide decrease per added amount of Fe(III) for all experiments (a-e). Grey dots indicate experiments with GFH as additive and the white square the one using $\mathrm{FeCl}_{3}$

\section{Kinetics of the reaction}

As obvious from Fig. 4, sulfide did not decrease just by bubbling air into the container (using the compressor) indicating that the oxidation of sulfide by air oxidation is too slow (not measurable over the monitored period). The reaction started directly upon Fe(III) addition. The speed of the reaction depended strongly on the type and amount of iron added to the system. When using the iron hydroxide GFH at low concentration $(<2.4 \mathrm{mmol} \mathrm{Fe}$ or $0.2 \mathrm{~g} / \mathrm{L})$, the reaction was relatively slow $(6 \mu \mathrm{mol}$ sulfide/minute will be removed) and stopped after about $0.3 \mathrm{mM}(10 \mathrm{mg} / \mathrm{L})$ sulfide was consumed (Fig. 12). This can be explained with a limited number of Fe(III) surface sites being available for reaction with the hydrogen sulfide. Once these available surface sites are consumed, the reaction is terminated and the residual GFH will not be available for further reaction with the sulfide. When offering a larger amount of iron hydroxide ( $>5 \mathrm{mM})$, the overall surface area increases and the rate of sulfide decrease is rather quick $(0.5-1 \mathrm{mmol} / \mathrm{min})$ and all sulfide was removed.

When using $\mathrm{FeCl}_{3}$ solution as additive, the reaction was not limited by surface sites but all iron was available for the reaction. Therefore, the reaction was much faster and less $\mathrm{Fe}(\mathrm{III})$ material was needed as additive. By adding only a minimum amount of $\mathrm{Fe}$ $(0.7 \mathrm{mM})$, the rate of sulfide removal is at least $0.03 \mathrm{mmol} / \mathrm{min}$ (Fig. 12). Clearly, the reaction is faster and more complete with this soluble additive. Moreover, a recycling of the material can be considered since after iron sulfide formation, the material would oxidize (in the presence of oxygen) again to an iron(III) hydroxide, which again can be reused for oxidizing the hydrogen sulfide by being reduced. This latter step would be similar to the reaction described for GFH—a surface controlled mechanism.

It can be assumed that microorganisms strongly affect the speed of sulfide oxidation and iron reduction as described for many environments in numerous studies (e.g. Geelhoed et al. 2009; Coleman et al. 1993). However, microorganisms need also a carbon source for their metabolic cycle. The measured content in organic carbon in the thermal water was very low $(0.2-0.4 \mathrm{mg} / \mathrm{L})$ and thus the contribution of microorganisms to 
the reaction kinetics in this particular system is probably little and the system predominantly abiotic, which however is yet to be confirmed.

\section{Conclusions}

A new method of treatment for geothermal fluids to remove hydrogen sulfide from the brine by adding $\mathrm{Fe}$ (III)-based additives was tested. Both types of $\mathrm{Fe}(\mathrm{III})$ additives (GFH particles and $\mathrm{FeCl}_{3}$ solution) that were injected into the fresh geothermal brine fully removed the hydrogen sulfide from the aqueous phase of a given volume. The redox reactions underlying this process are rather manifold due to the different species and redox states of the sulfur and iron phases. They can be summarized as oxidation of sulfide and reduction of Fe(III) and subsequently a re-oxidation of the iron by oxygen. The rates of sulfide consumption vary, depending on the type and amount of added $\mathrm{Fe}(\mathrm{III})$. The $\mathrm{FeCl}_{3}$ solution was proven to be much faster to oxidize the hydrogen sulfur as compared to the solid GFH phase indicating that dissolved iron is better available for the redox reaction. However, when using $\mathrm{FeCl}_{3}$ it has to be considered that moderate concentrations should be added, since otherwise the solution $\mathrm{pH}$ would be too low for the reduction of Fe(III), which remains in its redox state at low $\mathrm{pH}$ value. Moreover, a high acidity would provoke unwanted reactions such as corrosion. Therefore, it is recommended to remain with the reaction in the neutral $\mathrm{pH}$ range and keep the $\mathrm{FeCl}_{3}$ addition constantly low $(<1 \mathrm{mM})$. In contrast, when using GFH, the amount of additive is not limited. Since the reaction with ferric iron hydroxide is altogether slower, higher amounts of this material are recommended to add, because with increasing surface area of the iron particles the reaction speed also increases. To summarize, the main factors that control the described processes as well as the speed of the reactions are the amount and availability of $\mathrm{Fe}(\mathrm{III})$ as well as the solution $\mathrm{pH}$ value.

The application of this method for long-term geothermal operation requires an upscaling since the experiment was performed only with a limited volume of brine. For this, the installation of an equalizing tank is recommended, where the iron could be added into the thermal water before being further processed for bathing. Since data of this study gave good results for an iron concentration of $0.7 \mathrm{mmol} / \mathrm{L}$ added to the reaction container (corresponding to $38.5 \mathrm{~g}$ Fe per $\mathrm{m}^{3}$ produced brine) altogether $770 \mathrm{~g} / \mathrm{h}$ would be required at a production flow rate of $10 \mathrm{~m}^{3} / \mathrm{h}$ at the site. This calculation does not consider the recycling of the material after oxidation of the $\mathrm{Fe}$ (II) to Fe(III) hydroxide at aerobic conditions. This recycling allows to re-use the same amount of iron consistently and would strongly save material costs. This would be beneficial as compared to the previously applied method at the site. To test this recycling capacity, an additional field experiment is recommended to be carried out.

Generally, for implementation of the method in geothermal systems, the addition of iron into the brine should take place before fluid filtration and reinjection into the injection well. Another outcome of this study was that the tested HydroGeoFilt has been proven to be applicable at given geothermal conditions. For using the GFH as additive, the filter candles with 5 and $10 \mu \mathrm{m}$ have proven to be sufficient but for using the $\mathrm{FeCl}_{3}$ solution as additive, the formed suspensions yield smaller sized particles that were not 
all retained by the tested filter mesh sizes. It is recommended to first investigate smaller mesh sizes for these filters (e.g., 1-2 $\mu \mathrm{m}$ ) before method application at a geothermal site.

\section{Acknowledgements}

The authors kindly acknowledge Andrea Vieth-Hillebrand and Kristin Günther for measurements of organic components, Anja Schleicher for measuring the samples by X-ray diffraction, and Ilona Schäpan for measurements by scanning electron microcopy (all GFZ Potsdam). Many thanks to the operators at the geothermal site Oberlaa, especially to Erwin Wietowez for their interest of the project and kind support during field work. This project has been partially subsidized through the ERANET Cofund GEOTHERMICA (Project no. 731117), from the European Commission, RVO, FZJ-PtJ and EUDP, confound by the Federal Ministry of Economic Affairs and Energy (BMWi) based on a decision by the German Bundestages (Germany).

\section{Authors' contributions}

$\mathrm{SR}, \mathrm{Jl}, \mathrm{EF}, \mathrm{FJZ}$ and FE contributed to the manuscript by performing or evaluating the experiment described in the paper. The main author coordinated the experiments and wrote this manuscript. All authors read and approved the final manuscript.

\section{Funding}

All sources of funding for the research reported are declared in the acknowledgments within the manuscript.

\section{Availability of data and materials}

All datasets on which the conclusions of the manuscript rely are presented in the manuscript.

\section{Ethics approval and consent to participate}

In this study, no human participants, human data or human tissue was used. The manuscript does not report on or involve any animals, humans, human data, human tissue or plants.

\section{Competing interests}

The authors declare that they have no competing interests.

\section{Author details}

${ }^{1}$ Helmholtz Centre Potsdam GFZ German Research Centre for Geosciences, 14473 Potsdam, Germany. ${ }^{2}$ Hydroisotop $\mathrm{GmbH}, 85301$ Schweitenkirchen, Germany.

Received: 11 March 2020 Accepted: 6 July 2020

Published online: 14 July 2020

\section{References}

Badruzzaman M, Westerhoff P, Knappe DR. Intraparticle diffusion and adsorption of arsenate onto granular ferric hydroxide (GFH). Water Res. 2004;38(18):4002-12.

Baldacci A, Mannari M, Sansone F. Greening of geothermal power: an innovative technology for abatement of hydrogen sulphide and mercury emission. In: Proceedings of the World Geothermal Congress, Antalya, Turkey 2005; 2429.

Berner RA. Sulphate reduction, organic matter decomposition and pyrite formation. Philos Trans R Soc Lond Ser A. 1985;315(1531):25-38.

Cline JD. Spectrophotometric determination of hydrogen sulfide in natural waters 1. Limnol Oceanogr. 1969;14(3):454-8.

Coleman ML, Hedrick DB, Lovley DR, White DC, Pye K. Reduction of Fe(III) in sediments by sulphate-reducing bacteria. Nature. 1993;361(6411):436-8.

Cornell RM, Schwertmann U. The iron oxides: structure, properties, reactions, occurrences and uses. New York: Wiley; 2003.

Druschel GK, Hamers RJ, Luther GW, Banfield JF. Kinetics and mechanism of trithionate and tetrathionate oxidation at low pH by hydroxyl radicals. Aquat Geochem. 2003;9(2):145-64.

Feldbusch E, Regenspurg S, Banks J, Milsch H, Saadat A. Alteration of fluid properties during the initial operation of a geothermal plant: results from in situ measurements in Groß Schönebeck. Environ Earth Sci. 2013;70(8):3447-58.

Firer D, Friedler E, Lahav $\mathrm{O}$. Control of sulfide in sewer systems by dosage of iron salts: comparison between theoretical and experimental results, and practical implications. Sci Total Environ. 2008;392(1):145-56.

Geelhoed JS, Sorokin DY, Epping E, Tourova TP, Banciu HL, Muyzer G, Stams AJ, Van Loosdrecht MC. Microbial sulfide oxidation in the oxic-anoxic transition zone of freshwater sediment: involvement of lithoautotrophic Magnetospirillum strain J10. FEMS Microbiol Ecol. 2009;70(1):54-65.

Gutierrez O, Park D, Sharma KR, Yuan Z. Iron salts dosage for sulfide control in sewers induces chemical phosphorus removal during wastewater treatment. Water Res. 2010;44(11):3467-75.

Hansell A, Oppenheimer C. Health hazards from volcanic gases: a systematic literature review. Arch Environ Health. 2004;59(12):628-39.

Jia R, Tan JL, Jin P, Blackwood DJ, Xu D, Gu T. Effects of biogenic $\mathrm{H}_{2} \mathrm{~S}$ on the microbiologically influenced corrosion of C1018 carbon steel by sulfate reducing Desulfovibrio vulgaris biofilm. Corros Sci. 2018;130:1-11.

Kovalenko ON, Kundo NN, Kalinkin PN. Kinetics and mechanism of low-temperature oxidation of $\mathrm{H}_{2} \mathrm{~S}$ with oxygen in the gas phase. React Kinet Catal Lett. 2001;72(1):139-45.

Legmann H. The Bad Blumau geothermal project: a low temperature, sustainable and environmentally benign power plant. Geothermics. 2003;32(4-6):497-503.

May PM, Batka D, Hefter G, Königsberger E, Rowland D. Goodbye to $\mathrm{S}^{2-}$ in aqueous solution. Nat Commun. 2018;54(16):1980-3 
Mayrhofer C, Niessner R, Baumann T. Hydrochemistry and hydrogen sulfide generating processes in the Malm aquifer, Bavarian Molasse Basin, Germany. Hydrogeol J. 2014;22(1):151-62.

Milsch H, Giese R, Poser M, Kranz S, Feldbusch E, Regenspurg S. FluMo—a mobile fluid_chemical monitoring unit for geothermal plants. Environ Earth Sci. 2013;70(8):3459-63.

Müller DR, Friedland G, Regenspurg S. An improved sequential extraction method to determine element mobility in pyrite-bearing siliciclastic rocks. Int J Environ Anal Chem. 2017;97(2):168-88.

Nasution A, Takashima I, Muraoka H, Takahashi H, Matsuda K, Akasako H, Futagoishi M, Kusnadi DNanlohi F. The geology and geochemistry of Mataloko-Nage-Bobo geothermal areas, central Flores, Indonesia. In: Proceedings of World Geothermal Congress 2000, Beppu and Morioka, Japan: 2165-2170.

Puigdomenech I. Hydra/Medusa chemical equilibrium database and plotting software. Stockholm: KTH Royal Institute of Technology; 2004.

Ramasamy S, Singh S, Taniere P, Langman MJS, Eggo MC. Sulfide-detoxifying enzymes in the human colon are decreased in cancer and upregulated in differentiation. Am J Physiol Gastrointest Liver Physiol. 2006;291 (2):G288-96.

Regenspurg S, Brand A, Peiffer S. Formation and stability of schwertmannite in acidic mining lakes. Geochim Cosmochim Acta. 2004;68(6):1185-97.

Reiffenstein RJ, Hulbert WC, Roth SH. Toxicology of hydrogen sulfide. Annu Rev Pharmacol Toxicol. 1992;32(1):109-34.

Zötl JG. The spa Deutsch-Altenburg and the hydrogeology of the Vienna basin (Austria). Environ Geol. 1997:29(3-4):176-87.

\section{Publisher's Note}

Springer Nature remains neutral with regard to jurisdictional claims in published maps and institutional affiliations.

\section{Submit your manuscript to a SpringerOpen ${ }^{\odot}$ journal and benefit from:}

- Convenient online submission

Rigorous peer review

Open access: articles freely available online

- High visibility within the field

Retaining the copyright to your article

Submit your next manuscript at $\boldsymbol{\Delta}$ springeropen.com 